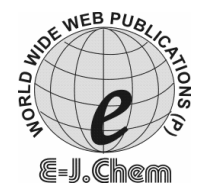

http://www.e-journals.net

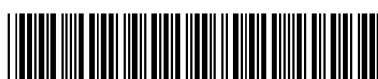

ISSN: 0973-4945; CODEN ECJHAO

E-Journal of Chemistry

2010, 7(3), 733-738

\title{
Assessment of the Deterioration in Physiochemical and Microbiological Quality of Shivnath River Water in Durg District, India
}

\author{
SEEMA.A.BELORKAR \\ Microbiology Research Laboratory, Department of Microbiology, \\ St.Thomas College, Bhilai,(C.G) 490006, India. \\ seema_a1811@rediffmail.com
}

Received 27 August 2009; Revised 11 November 2009; Accepted 5 January 2010

\begin{abstract}
The water samples collected from Shivnath river in Durg Dist., India, were analyzed for physical properties like color, temperature, turbidity and odor, chemical properties like $\mathrm{pH}$, alkalinity, total hardness, calcium hardness, magnesium hardness, total solids \{Total dissolved solids (TDS) and total suspended solids (TSS)\}, sulphates, nitrates were analyzed. Microbiological characteristics like detection of coliforms, quantitative analysis and most probable number (MPN) of coliforms was also performed. Incidences of Escherichia coli 0157 (Thermo tolerant strain) and Salmonella species were analyzed. All stated properties were analyzed for both upstream and downstream sampling points to determine the effect of residential and industrial discharges on the quality of river water. The addition of discharges has shown many fold increase in all the analyzed physiochemical parameters. The MPN/100 mL for upstream sample was 900 and down stream sample showed rises up to 1600 . The heterotrophic plate count (HPC) also increased from $1.30 \times 10^{4} / 100 \mathrm{~mL}$ to $1.53 \times 10^{4} / 100 \mathrm{~mL}$. Incidences of E.coli 0157 (Thermo tolerant strain) and Salmonella species were both found even before the addition of discharges.
\end{abstract}

Keywords: MPN, E.coli 0157, TDS and TSS, River water quality.

\section{Introduction}

Water is the most basic and vital resource of our planet. According to the UN (United Nations) reports, 1978 consumable water levels are up to $2.7 \%$ of the total water content. $1 \%$ of the ground water levels are threatened either directly or indirectly by pollution ${ }^{1}$. River water acts as receiving end of industrial wastes, residential area discharges which increase the pollution stress on these surface water bodies ${ }^{2}$. 
Non pathogenic faecal organisms are best indicators of faecal pollution. However, in all cases faecal coliform counts and Escherichia coli is used as the major tool in the assessment of the health risks borne by pathogens in water ${ }^{3}$.

Many researchers constantly undertake work on assessment of physiochemical and microbiological quality of water bodies in different parts of the country ${ }^{4-7}$. In Chattisgarh state many small and big rivers co-originate. Shivnath river is main tributary of river Mahanadi. After originating from Panbara in Ambagarh tehsil of Rajnandgaon, it flows initially north wards about $40 \mathrm{~km}$ and at Ambagarh chouky it turns at right angles to flow in the east direction.

It is the second important river of chattisgarh in terms of carrying of water and length measured in the state. It flows about $290 \mathrm{~km}$ through Rajnandgaon, Durg and Janjgir, Champa District. The main tributaries are Lilagar, Maniyari, Surahi, Tandula etc. Shivnath is facing a great deal of pollution due to dumping of variety of wastes. The present study focuses on assessment of impact of the discharges on the physicochemical and microbiological quality of Shivnath river water in Durg Dist.

\section{Experimental}

River water samples were collected at two different sites hence forth cited as upstream and down stream. Shivnath River enters Durg; the spot chosen for upstream sampling was at Shivnath Bridge, near Vrindavan Hotel, Durg. The Pulgaon Channel which is one of the major sources of residential and industrial area discharges mixes into the river at Pushpavatika (Ganjpara, Durg) and is referred as downstream in the observations given below.

\section{Collection of water samples for physiochemical analysis}

Five liters of grab samples were collected. The samples were collected in plastic containers. The collected samples were analyzed for physiochemical analysis.

\section{Collection of water samples for microbiological analysis}

The water samples were collected in clean, sterilized narrow mouthed glass bottle of $250 \mathrm{~mL}$ capacity .The collected samples were analyzed for microbiological parameters.

\section{Methodology}

APHA $^{8}$ (American Public health Association) was used for analysis. The method used for studying physical properties like color was by visual observation and odor by smelling, temperature by thermometer $\left(0^{\circ}-1000^{\circ}\right)$, turbidity by turbidometer, chemical properties like $\mathrm{pH}$ by $\mathrm{pH}$ meter, DO, BOD, COD, alkalinity, total hardness, calcium hardness, magnesium hardness by titrometric methods, total solids (TDS and TSS) by gravimetric method, sulphates, nitrates were analyzed by colorimetric method. Microbiological properties like detection of coliforms, quantitative analysis (MPN) of coliforms, incidences of E.coli 0157(Thermo tolerant strain) and Salmonella species were analyzed for both upstream and downstream sampling. All the chemicals used were of analytical grade.

\section{Results and Discussion}

The study revealed that, addition of discharges into the river water has enhanced the pollution load of all the parameter taken under study like TDS, TSS, alkalinity, hardness, (Biological oxygen Demand) BOD, COD (Chemical Oxygen Demand), nitrates, nitrites and sulphates. The results of analysis are also represented in graphical manner. 


\section{pH, Temperature, Turbidity, Color and Odor}

The upstream and down stream water samples were found to be colorless and odorless with $23.8\left({ }^{\circ} \mathrm{C}\right)$ and $25.2\left({ }^{\circ} \mathrm{C}\right)$ temperature respectively. The permissible limit for $\mathrm{pH}$ is 6.5 to 8.5 for use of the river water for drinking purpose. The addition of the discharges resulted in increase of the $\mathrm{pH}$ beyond the $\mathrm{BIS}^{9}$ (Bureau of Indian Standards) tolerance limit. Table 1 reports the observation of $\mathrm{pH}$, temperature, turbidity, color and odor.

Table 1. $\mathrm{pH}$, temperature, turbidity, color and odor of upstream and downstream samples.

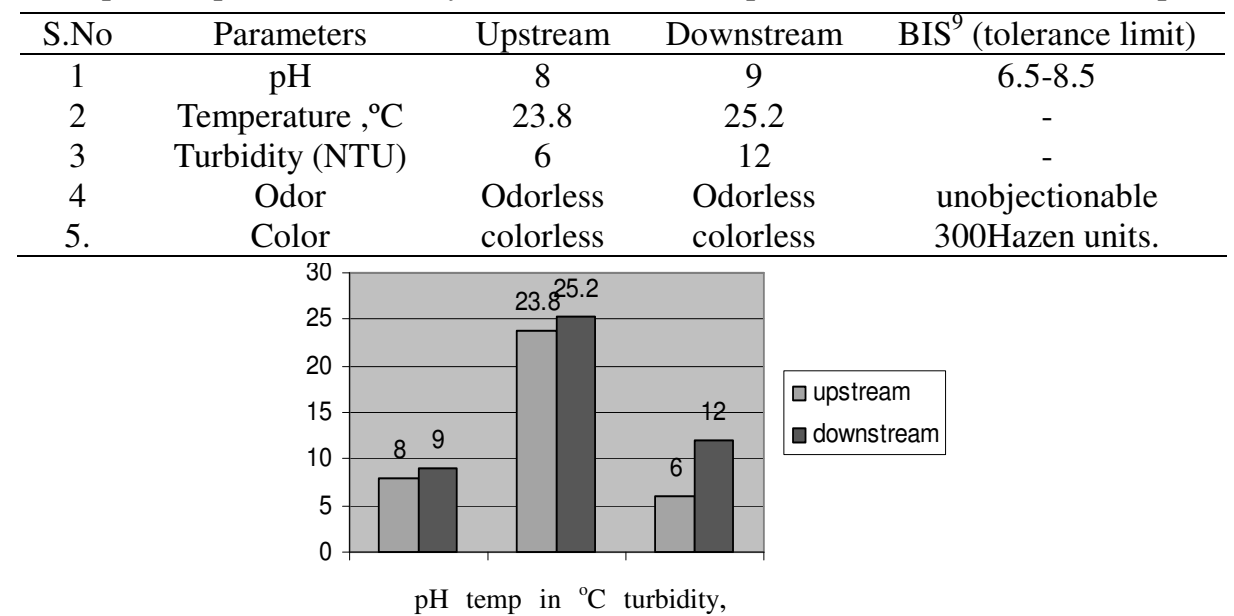

Figure 1. Comparisons of $\mathrm{pH}$, Temperature and turbidity of upstream and downstream samples.

\section{TDS and TSS}

The values of TDS were found to be within limits even after the effluent introduction into the river. Observations of the stated parameters are given in Table 2.

Table 2. TDS and TSS of upstream and downstream samples.

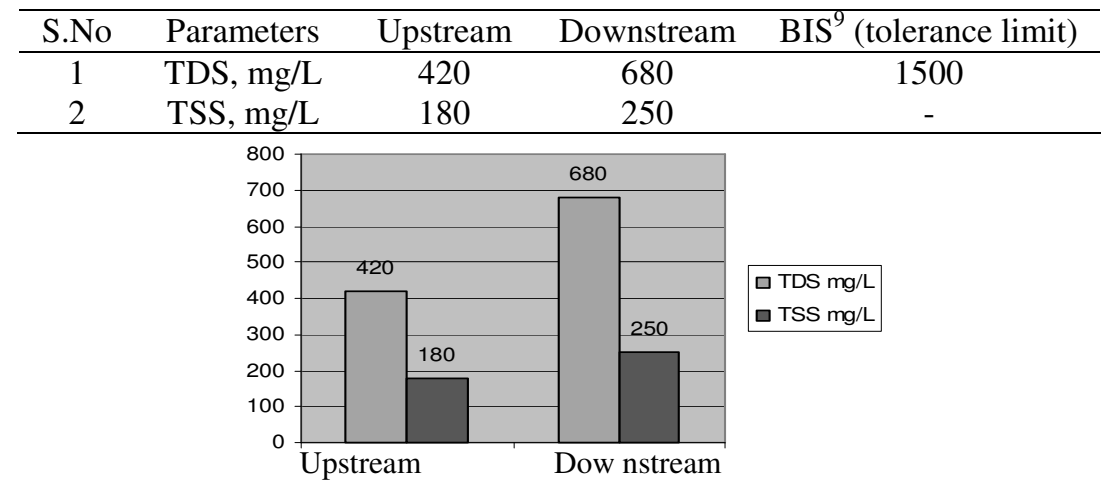

Figure 2. TDS and TSS of upstream and downstream samples.

$D O, B O D$ and $C O D$

The BOD values of both the samples were observed to be quite high than the BIS tolerance limit indicating high organic matter content in river water. Observations of the stated parameters are given in Table 3. 
Table 3. DO, BOD, COD of upstream and downstream samples.

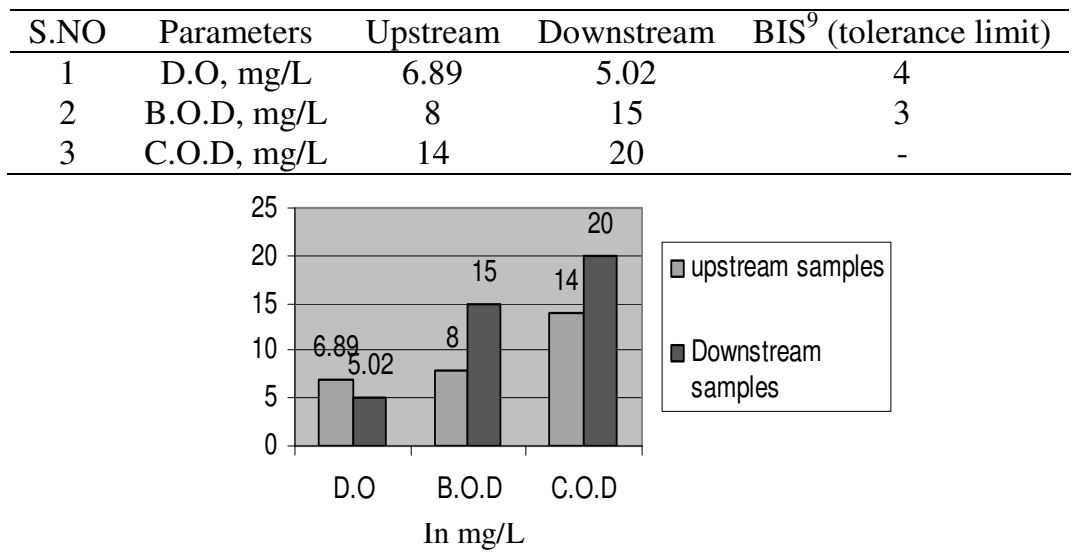

Figure 3. DO, BOD and COD (in mg/L) upstream and downstream samples.

\section{Hardness, Sulphates, Nitrates and Nitrites}

The introduction of the effluent caused the nitrate of river water to exceed the tolerance limit. According to the BIS 10500: 1991 the desirable limit of calcium should be $75 \mathrm{mg} / \mathrm{mL}$ and the permissible limit is $400 \mathrm{mg} / \mathrm{mL}$. The calcium content of river water was observed to exceed the desirable limit but was within permissible limit. Observations of the stated parameters are given in Table 4.

Table 4. Hardness, sulphates, nitrates and nitrites of upstream and downstream samples.

\begin{tabular}{clccc}
\hline S.No & \multicolumn{1}{c}{ Parameters } & Upstream & Downstream & BIS $^{9}$ (tolerance limit) \\
\hline 1 & Ca hardness, mg/L & 60 & 85 & $75-$ \\
2 & Mg-hardness, mg/L & 180 & 260 & - \\
3 & Sulphates, mg/L & 40 & 10 & 400 \\
4 & Nitrates, mg/L & 20 & 60 & 50 \\
5 & Nitrites, mg/L & 4 & 15 & - \\
\hline
\end{tabular}

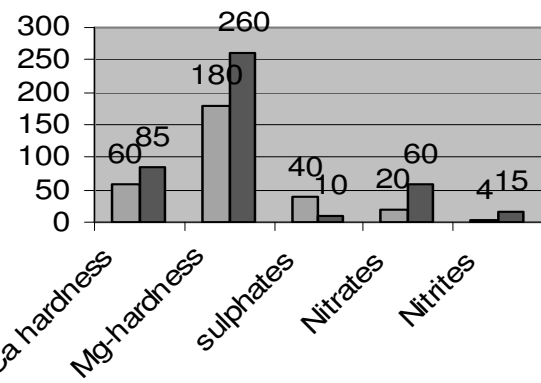

$\square$ Upstream

$\square$ Downstream

Figure 4. Hardness, sulphates, nitrates and nitrites of upstream and downstream samples represented in $\mathrm{mg} / \mathrm{L}$.

\section{Alkalinity}

The river water shows increase in alkalinity beyond the limit. This is attributed to the routine washing and bathing activities conducted at the banks of the river. Observations of the stated parameters are given in Table 5 . 
Table 5. Alkalinity of upstream and downstream samples.

\begin{tabular}{clccc}
\hline S.No & Parameters & Upstream & Downstream & BIS $^{9}$ (tolerance limit) \\
\hline 1 & Alkalinity, mg/L & 180 & 290 & 200( BIS 10500:1991 $)^{\mathrm{IT}}$ \\
2 & $\begin{array}{l}\text { Phenolphthalein - } \\
\text { Alkalinity, mg/L }\end{array}$ & 20 & 10 & - \\
3 & $\begin{array}{l}\text { Methyl red - } \\
\text { Alkalinity, mg/L }\end{array}$ & 170 & 260 & - \\
\hline
\end{tabular}

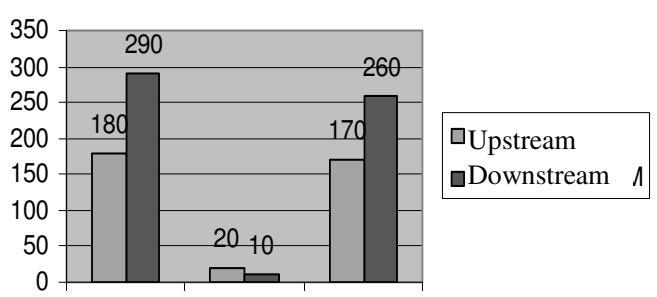

Alkalinity $\mathrm{P}$-Alkalinity M-Alkalinity $\quad(\mathrm{P}=$ Phenolphthalein; $\mathrm{M}=$ Methyl red $)$

Figure 5. Alkalinity upstream and downstream samples.

\section{Microbiological analysis}

Table 6. Standards of acceptable total coliform in inland surface water, according to Indian Standards $2296^{10}$. (Indian standards of drinking water-specification BIS 10500: 1991) .

\begin{tabular}{cll}
\hline Classification & \multicolumn{1}{c}{ Uses } & Acceptable standard \\
\hline A & $\begin{array}{l}\text { Drinking water without conventional } \\
\text { treatment, but after disinfecting }\end{array}$ & 50 or less \\
B & $\begin{array}{l}\text { Outdoor bathing } \\
\text { Drinking water source with conventional } \\
\text { treatment followed by disinfecting }\end{array}$ & 500 \\
C & $\begin{array}{l}\text { Propagation of wildlife and fisheries } \\
\text { Irrigation, industrial cooling \& }\end{array}$ & No standard \\
D & controlled waste disposal & No standard \\
E & .
\end{tabular}

Table 7. Microbiological analysis of upstream and downstream samples.

\begin{tabular}{llll}
\hline S.No & \multicolumn{1}{c}{ Experiment } & Upstream & Downstream \\
\hline 1. & MPN $/ 100 \mathrm{~mL}$ & 900 & 1600 \\
2. & HPC & $1.30 \times 10^{4} / 100 \mathrm{~mL}$ & $1.53 \times 10^{4} / 100 \mathrm{~mL}$ \\
3. & Incidences of Salmonella spp & Present & Present \\
4. & Incidences of 0157 E.coli & Present & Present \\
\hline
\end{tabular}

Microbiological studies revealed that the effluents induced microbial growth in the river water by increasing the MPN from 900 to $1600 / 100 \mathrm{~mL}$. The HPC of upstream river water sample was $1.30 \times 10^{4} / 100 \mathrm{~mL}$. The downstream sample revealed the increased value of $1.53 \times 10^{4} / 100 \mathrm{~mL}$. Incidences of Salmonella spp and 0157 E.coli were found in both upstream and downstream samples. According to the BIS standards the water is unsuitable for bathing . Raw river water cannot be used for drinking purpose.

\section{Conclusion}

The above studies reveal that there was slight increase in physiochemical parameters . The BOD, calcium content and alkalinity exceeded the BIS limits. Significant impact was found on microbiological characteristics. The MPN of coliforms nearly doubled. The quality of 
river water deteriorated and cannot be used for bathing purpose .The river water is unsuitable for drinking without any disinfection.

\section{Acknowledgment}

This work was supported by the minor research project of University grants commission. The author acknowledges her sincere thanks to the Head of the Department, Dr. M.G. Roymon, Principal of the College Dr. Renny George for their support and cooperation during the tenure of the project.

\section{References}

1. Davis M L and Cornwell D A, Introduction to Environmental Engineering. Mc Graw Hill. PWS, Publishers, New York, 1991, 93.

2. Ajayi S O and Ossian O, Environ Pollut., (Series B), 1981, 2, 87-95.

3. Byamukama D, Kansiime F, Mach R L and Farnleitner A H, Appl Environ Microbiol., 2000, 66, 864-868.

4. Nath D, J Inland Fish Soc India, 2001, 33(2), 37-41.

5. Vijender Singh, Res J Chem Environ., 2006, 10(3), 62-66.

6. Mishra A and Bhatt V, E Journal of Chemistry, 2008, 5(3), 487-492

7. Ramteke P N, Battacharjee J W , Pathak S P and Karla N, J Appl Bacteriol., 1992, 72, 352 .

8. Standard methods for the examination of water and wastewater $\left(20^{\text {th }}\right.$ Ed.). Washington DC, USA. APHA (American Public Health Association), AWWA (American Water Work Association) and WEF (Water Environment Federation), Washington DC, 1999.

9. Tolerance limits for inland surface waters subject to pollution. Bureau of Indian Standard, New Delhi, (BIS: 2296-1982.), 1982.

10. Indian standards of drinking water-specification, BIS 10500: 1991. 


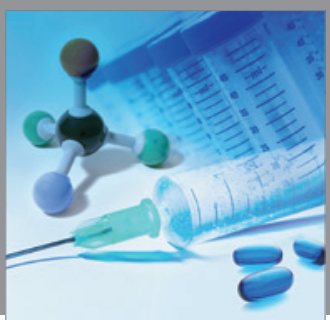

International Journal of

Medicinal Chemistry

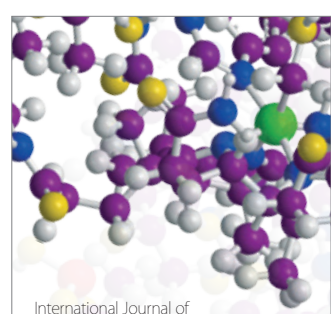

Carbohydrate Chemistry

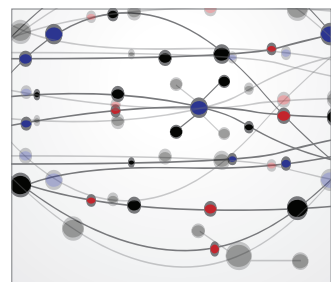

The Scientific World Journal
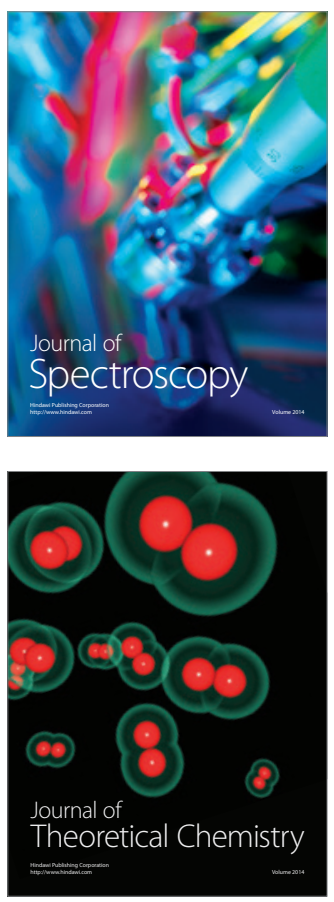
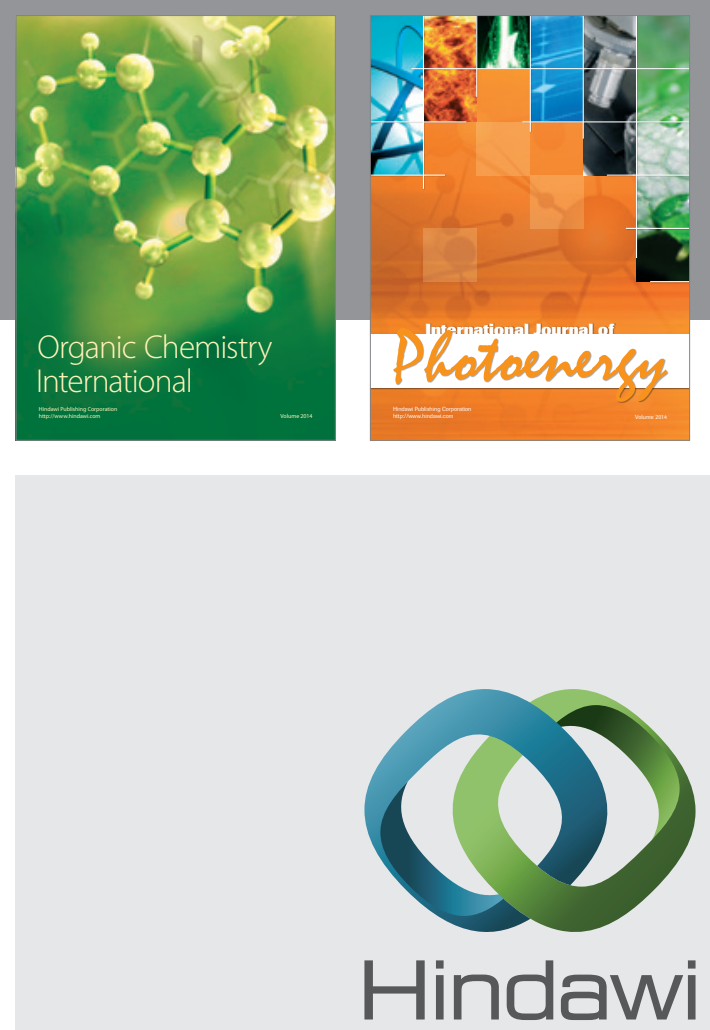

Submit your manuscripts at

http://www.hindawi.com
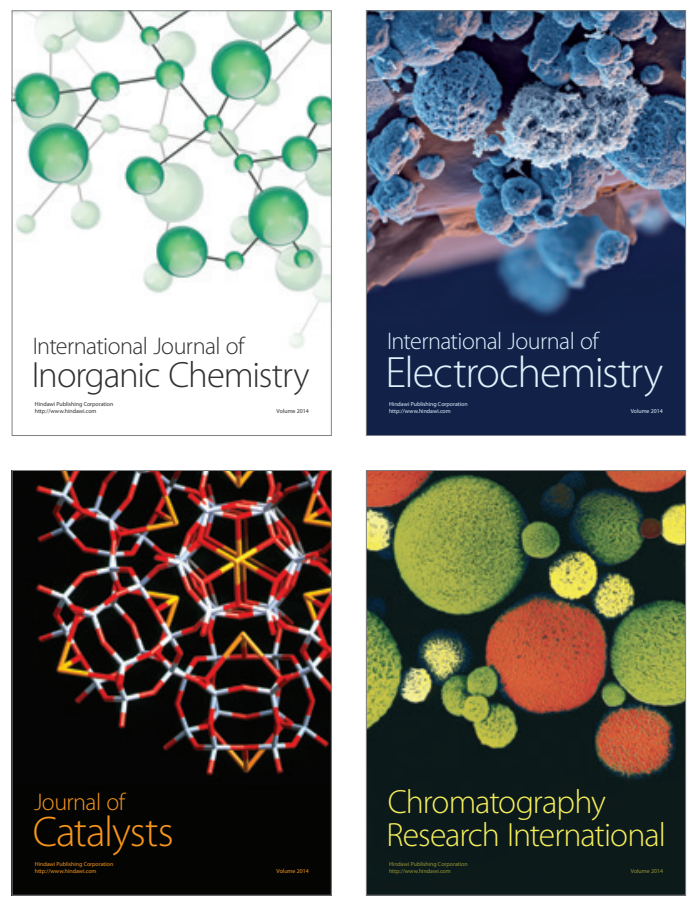
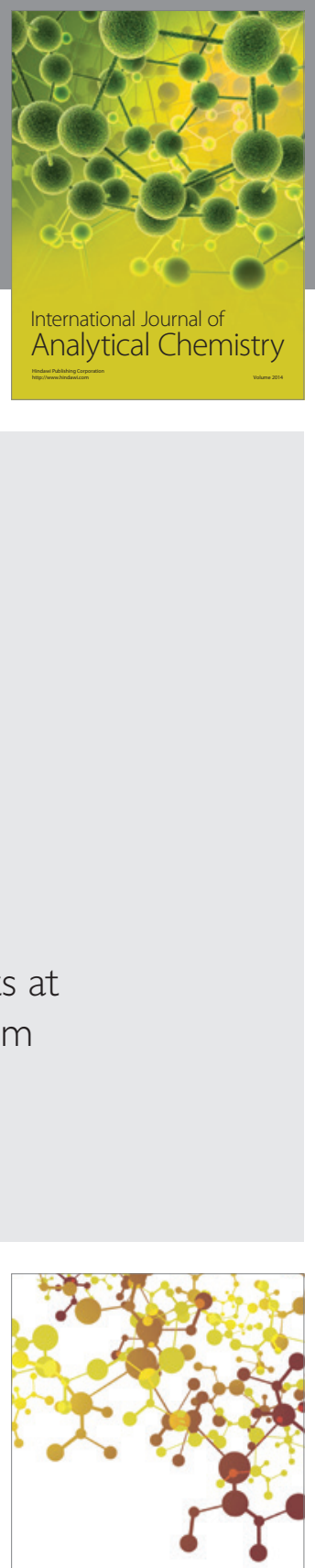

Journal of

Applied Chemistry
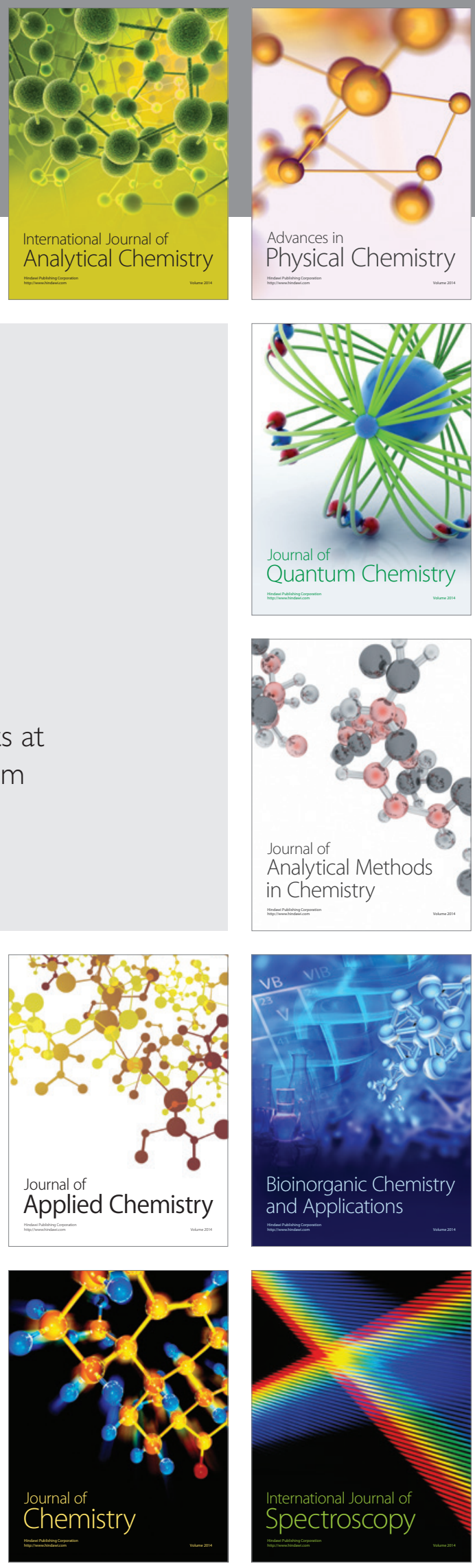